\title{
NEW ALTERNATIVE FOR WOUND PROTECTION IN LAPAROSCOPIC COLECTOMY
}

\author{
Nova alternativa para proteção da ferida cirúrgica em colectomia laparoscópica
}

José Jorge da SILVA, Rafael Melo SILVA, Kárin Kneipp COSTA

From the Departamento de Ginecologia e Obstetrícia e Departamento de Clínica Cirúrgica, Hospital Universitário Cassiano Antônio de Moraes, Universidade Federal do Espírito Santo (Department of Obstetrics and Gynecology and Department of Surgery, University Hospital Cassiano Antonio Moraes, Federal University of Espírito Santo), Vitória, ES, Brazil

$\begin{array}{ll}\text { HEADINGS - } & \text { Equipment and supplies } \\ \text { Colectomy. } & \text { Laparoscopy. Colonic }\end{array}$ neoplasms. Endometriosis.
ABSTRACT - Background: Large number of surgical services use laparoscopy to approach the colon. One of the concerns on the resection using this way is the high rate of cancer relapse at in- and outlet site of the surgical instruments. Aim: To describe a protective device for surgical isolation in laparoscopic colectomy. Methods: The device is made of sterile polyethylene plastic cover used to protect the fiber optic cable in laparoscopic surgery and one $20 \mathrm{Fr}$. urethral catheter working as a conduit. Results: The device was used in six laparoscopic colectomies, three for adenocarcinoma of the colon and three for intestinal endometriosis. It was effective to avoid contact of the specimen with the abdominal wall, in order to reduce the risk of implantation of cancer or endometriotic cells and surgical site infection. The device was made intraoperative at all surgeries and allowed good visualization in laparoscopy and maintenance of the pneumoperitoneum. It cost $R \$ 22,00$ (approximately US\$10), R\$14.50 related to the plastic cover and $R \$ 7.50$, the urethral tube. The production time of the device and its installation in the abdominal cavity was measured in each procedure and was, on average, respectively, of $66 \mathrm{~s}$ and $25 \mathrm{~s}$. Conclusion: The device proved to be feasible, not requiring any special training and can be performed by the surgical team itself, even at institutions with limited resources.

\section{Correspondence:}

Rafael Melo Silva

E-mail: rafasilv@gmail.com

Financial source: none

Conflicts of interest: none

Received for publication: 23/10/2014 Accepted for publication: 08/01/2015

DESCRTORES - Equipamentos e Provisões Colectomia. Laparoscopia. Neoplasias do colo. Endometriose.
RESUMO - Racional: Grande número de serviços de cirurgia têm abordado laparoscopicamente do cólon. Uma das preocupações na ressecção dessa forma é o alto índice de recidivas de neoplasia nos orifícios de entrada dos instrumentais cirúrgicos. Objetivo: Descrever um dispositivo protetor para isolamento de peça cirúrgica em colectomia laparoscópica. Métodos: O dispositivo é produzido por meio de plástico de polietileno estéril que usualmente é utilizado no envolvimento do cabo de fibra ótica em videocirurgia, como proteção, e por uma sonda uretral de $20 \mathrm{Fr}$, funcionando como um pertuito ou conduto. Resultados: O dispositivo foi utilizado em seis colectomias laparoscópicas, três por adenocarcinoma de cólon e três por endometriose intestinal. Nestas operações, foi facilmente confeccionado no transoperatório. Mostrou-se efetivo para evitar o contato da peça cirúrgica com a parede abdominal, com o objetivo de reduzir o risco de implantação de células cancerosas ou endometrióticas e de infecção de sítio cirúrgico. Permitiu boa visualização na laparoscopia e manutenção do pneumoperitônio. Seu custo foi de $R \$ 22,00$, sendo $R \$ 14,50$ referentes à capa plástica e $R \$$ 7,50 , à sonda uretral. O tempo médio de confecção do dispositivo e de sua instalação na cavidade abdominal foi, respectivamente, de $66 \mathrm{~s}$ para confeç̧ão e de $25 \mathrm{~s}$ para instalação. Conclusão: A confecção do dispositivo ora apresentado mostrou-se viável, não requerendo qualquer treinamento especial e podendo ser executada pela própria equipe cirúrgica com custos reduzidos.

\section{INTRODUCTION}

I n recent years many surgical services have addressed the colon laparoscopically, both for the treatment of benign diseases as well as for tumors, with similar results to laparotomy ${ }^{5,6}$.

Initially, the laparoscopic surgical treatment of colon diseases was restricted to malignant cases. The concern was in relation to tumor resection, ie if it assures appropriate oncologic attendance and, also, with the high rate of cancer relapse in the incisions used by laparoscopic surgical devices ${ }^{3}$. Studies have shown alarming recurrence of colonic neoplasia in these incisions in up to $21 \%{ }^{12}$. This led, in mid90s, the American Society of Colon and Rectal Surgeons to recommend that the treatment of colon cancer by laparoscopy should be performed only in controlled trials ${ }^{3}$.

Several studies were conducted to elucidate the reason for this so high incidence ${ }^{4}$. In 2007 Fleshman et al, based on the COST study (tested with followup of five years), showed that there is no statistical difference in tumor recurrence in the surgical wound when comparing laparotomic or laparoscopic colectomy ${ }^{6}$. Other studies corroborate this finding and found that most responsible for this high frequency of recurrence were technical devices related to laparoscopy - under development at that time ${ }^{4}$. 
The surgical wound provides rich environment factors that support the growth of cancer cells. The large enough contact of these cells in the incision allows them to be implanted and developed. It is therefore crucial, in order to avoid this complication, to prevent contact of tumor cells with the abdominal wall ${ }^{4}$.

Endometriosis, although considered benign, has typically neoplastic characteristics, with invasion capacity to adjacent tissue and also causing distant implantation ${ }^{2}$, and similarly to cancer, can be implanted in the abdominal wall ${ }^{10}$. The pathophysiological explanation for this behavior is controversial, but the metastatic theory is advocated by some authors, who maintain that the handling and the contact of endometrial tissue with the surgical incision would be a condition for the development of the disease in this site ${ }^{1,7,10,14}$.

Routine use of protective devices to isolate the intestine during its withdrawal from the abdominal cavity, can be useful in the prevention of cells implantation into the abdominal wall. In addition, the decrease of the exchange of surgical instruments through the portals, careful handling to avoid the trauma of surgical specimen and control of pneumoperitoneum loss, are other important care that should also be observed ${ }^{1,4,13}$.

In addition, some studies have shown that the use of specimen protector on withdrawal from cavity in digestive operations reduces the occurrence of site infection ${ }^{8,9,15,16}$. This complication is very common in colorectal surgeries, reaching ratio of $26 \%$ in some studies ${ }^{11}$. According to published data, the proportion drops from $22.7 \%$ without the protective use to $4.7 \%$ when the device is used ${ }^{15}$. In laparoscopy, the risk of infection is lower, but the numbers are still relevant $(6.6 \%)^{11}$.

Thus, it is advisable to standardize medical practice using devices that allow the isolation of the surgical specimens during its withdrawal in laparoscopic procedures in patients with colon cancer or intestinal endometriosis s.5.16. $^{25}$ Considering the high prevalence of disease in focus, it is important to facilitate the effective production of protective devices at low cost, to enable the wide use of this type of device.

The objective of this study is to describe a sterile device for specimen isolation in laparoscopic colectomy.

\section{METHODS}

The study was conducted at Hospital Santa Rita and University Hospital Cassiano Antônio de Morais, Vitória, ES, Brazil, after approval by the Ethics in Research Committee of Santa Casa de Misericórdia under number 121/2011.

The use of the device occurred in six patients, who were informed about the study and signed a consent form. Were selected by convenience - three patients with adenocarcinoma and three of intestinal endometriosis - and underwent laparoscopic colectomy. In surgical procedures were used automatic staplers for anastomosis of intestinal segments. The surgical wound site was evaluated postoperatively in all patients.

Preparation technique of the protective device

The materials used were: 1 ) polyethylene sterile plastic used in laparoscopic surgery to surround the fiber optic cable, and 2) urethral catheter $20 \mathrm{Fr}$ in diameter. The catheter was shaped as a ring. The plastic was then inserted through the ring and everted completely to form a hollow cylinder - as a conduit - with about $20 \mathrm{~cm}$ long (Figure 1).

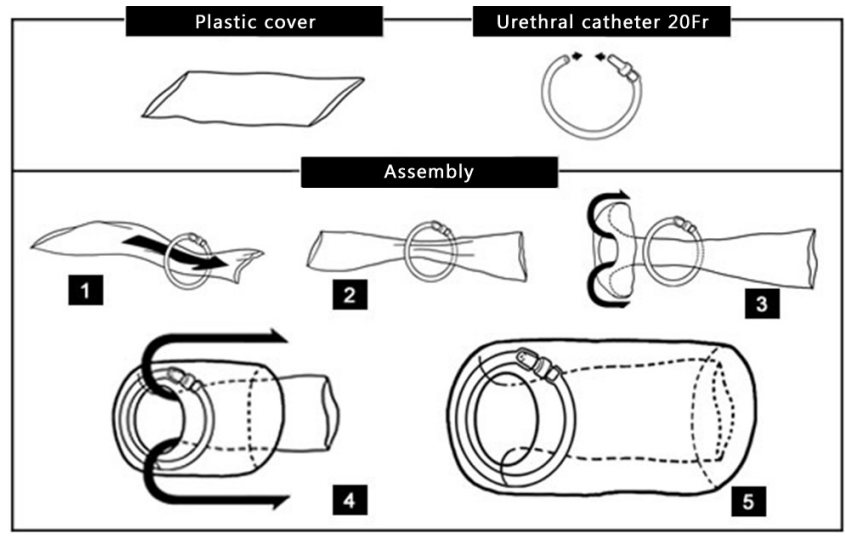

FIGURE 1 - Materials and assembly of the protective device

After this step, the plastic edge of the conduit was sealed by a Kelly clamp (Figure 2). The ring formed by the catheter was then collapsed between the surgeon's fingers before insertion into the abdominal cavity, which occurred through a transverse $5 \mathrm{~cm}$ incision above the pubis. Inside the cavity, the counterforce of urethral catheter caused the ring to open up, positioning itself in the parietal peritoneum around the incision (Figure 3).

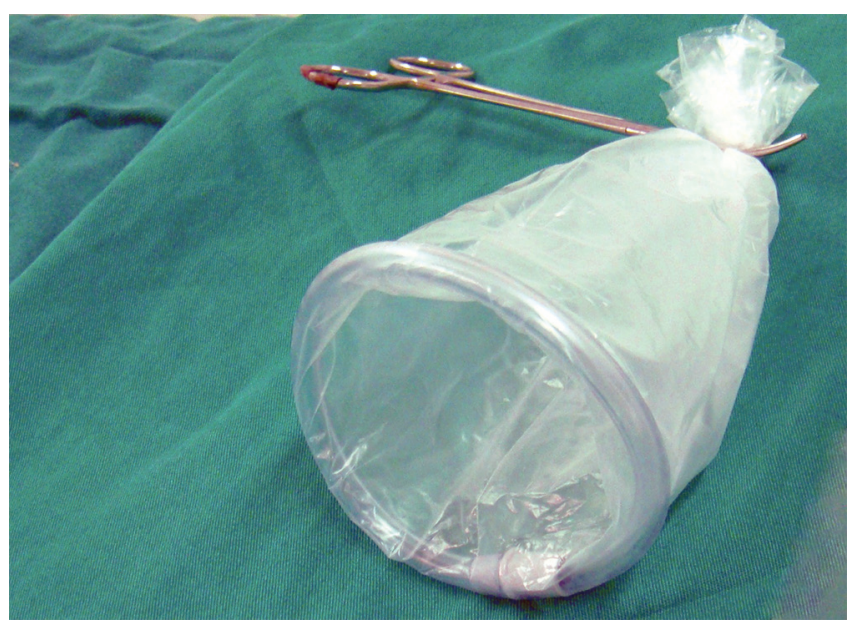

FIGURE 2 - Device sealed by Kelly forceps

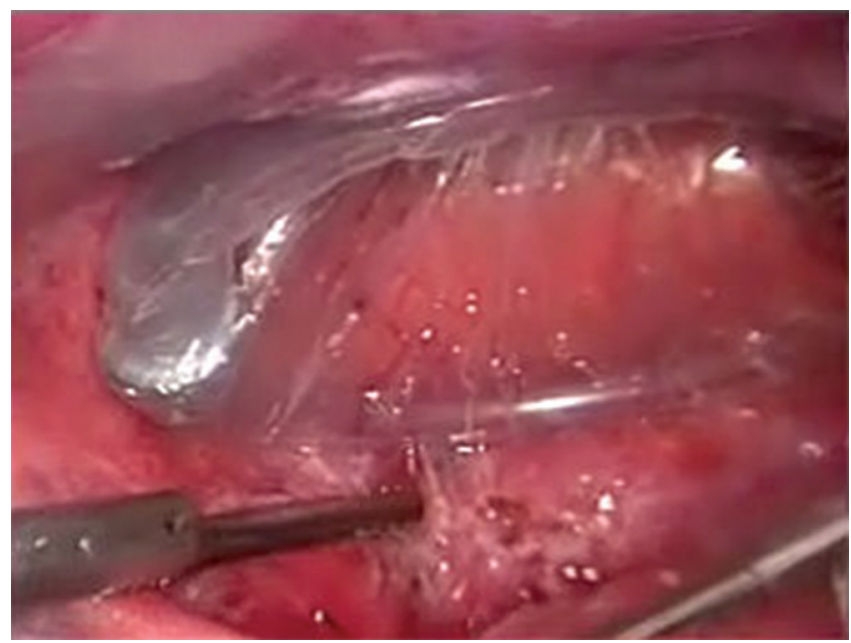

FIGURE 3 - Ring into the abdominal cavity around the incision

The sealed conduit was inflated by pneumoperitoneum and the plastic cover was rotated around its own axis, returning the gas to the abdominal cavity. Another Kelly clamp was used to grasp the nearest portion of the plastic cover to the ring 
(at the incision), allowing the first clamp be released and the end of the conduit be freed. After dissection of the affected intestinal segment, was introduced a grasping forceps in the free end of the conduit, and the surgeon compressing the plastic cover with his hand against this clamp, maintained pneumoperitoneum after detaching the second Kelly clamp. The steps described before since insertion of the device into the abdominal cavity, are shown in Figure 4.

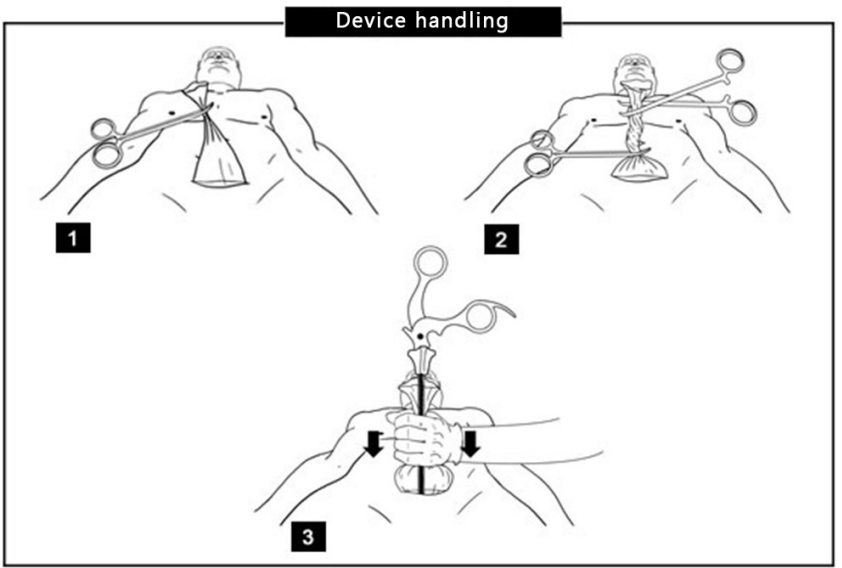

FIGURE 4 - Device handling

Finally, it was possible to achieve the segment that was externalized with the grasping forceps; at this time, the pulled gut occupied the device lumen and prevented air leakage, allowing the surgeon to do the external resection of the specimen (Figure 5). After the manipulation, the intestine was reinserted into the cavity and the edge of the orifice was sealed again with a Kelly clamp, proceeding with the laparoscopic operation.

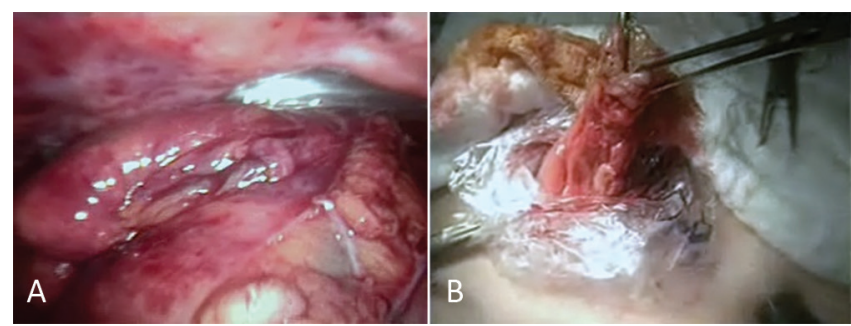

FIGURE 5 - Intestine was exteriorized through the orifice $(A)$ and resected outside the abdominal cavity (B)

\section{RESULTS}

In the three cases of colon adenocarcinoma right colon was involved at early stage of the disease, with tumors restricted to the intestinal wall. The affected bowel segment was externalized through the device, being resected with laterolateral anastomosis - terminal ileum with transverse colon - using linear stapler with $80 \mathrm{~mm}$ cartridge.

The three cases of bowel endometriosis had involvement of the rectosigmoid junction. In such cases, after dissection of the affected intestine, was used an articulated linear endoscopic stapler of $45 \mathrm{~mm}$ in upper rectal disease free, sectioning the intestinal segment proximal to the lesion to be resected, and stapling the distal portion. The proximal part was then externalized through the orifice and resected. In the remaining segment was inserted circular stapler warhead, being contained by purse suture. Then the specimen was returned to the abdominal cavity. Rectally, was then introduced the second part of the circular stapler, which has been coupled to the warhead in order to complete the anastomosis between the remaining portion of the colon and rectum. The integrity of the anastomosis was confirmed by blowing up air through Foley catheter via rectal route, known as "tire repairman maneuver."

In one of the cases of endometriosis, following the procedure described above and during the finalization of the abdominal cavity, was found an implantation of $3 \mathrm{~cm}$ of the disease in the cecum. Due to lack of laparoscopic material for further operation it was converted to laparotomy, being enlarged the incision and performed right colectomy without use of the protective device.

Each device cost approximately US\$10, referring to the plastic cover and the urethral catheter. The average time for device manufacturing was 66 seconds, and conduit insertion into the abdominal cavity was 25 seconds - from the parietal peritoneum incision to insertion of the ring with plastic cover filled by pneumoperitoneum (Table 1 ).

TABLE 1 - Time for device manufacture and control of pneumoperitoneum after the incision of the parietal peritoneum in the chronological order of operations

\begin{tabular}{|c|c|c|}
$\begin{array}{c}\text { Colectomies in } \\
\text { chronological order }\end{array}$ & $\begin{array}{c}\text { Time for device } \\
\text { manufacturing } \\
\text { (minutes) }\end{array}$ & $\begin{array}{c}\text { Time to control the } \\
\text { pneumoperitoneum } \\
\text { (seconds) }\end{array}$ \\
\hline $1^{\text {st }}$ procedure & $01: 50$ & 28 \\
\hline $2^{\text {nd }}$ procedure & $01: 08$ & 22 \\
$3^{\text {rd }}$ procedure & $00: 58$ & 30 \\
$4^{\text {th }}$ procedure & $00: 54$ & 25 \\
\hline $5^{\text {th }}$ procedure & $01: 00$ & 24 \\
\hline $6^{\text {th }}$ procedure & $00: 48$ & 21 \\
\hline Average time & $01: 06$ & 25 \\
\hline
\end{tabular}

The part of the device that was inserted into the abdominal cavity allowed good visualization in laparoscopy.

The patient with endometriosis with operation converted to laparotomy developed an abscess on the $7^{\text {th }}$ postoperative day. Drainage and antibiotics, solved the situation. The remaining cases did not present complications during the follow-up period of 30 days.

\section{DISCUSSION}

The presented device proved to be an alternative of low cost, easy to manufacture, effective to prevent contact of the specimen with the abdominal wall and maintaining pneumoperitoneum in laparoscopic operation.

The removal of the colon without contact with the surgical wound by laparoscopy is still a challenge for most surgeons in our country. Companies that provide laparoscopic material - to the date of this article -, do not routinely provide any kind of conduit device that allows the viscera externalization, as described herein. The device offers the possibility of maintaining the pneumoperitoneum - paramount in laparoscopic procedures - allowing careful review of the abdominal cavity even after intestinal resection and externalization. In all cases of endometriosis in this series, was possible to maintain the pneumoperitoneum to test the integrity of the anastomosis performed laparoscopically and, in one instance, the review showed other unidentified lesions in the initial inventory.

The low cost of manufacture of this product is an unquestionable advantage in the context of a national health system, with lack of resources and the high prevalence of the diseases under discussion. Seeking in the market other protective devices for colectomy, it was found that there are many options. The name Alexis ${ }^{\circledR}$ device of Applied Medical has an average value of US\$70 - minus import costs, taxes and intermediaries -, so, much more expensive than device presented here. Parts of the device are materials often used in 
health institutions, making the use of a viable tool in centers with fewer resources. Its easy making with no need of special training, is perfectly feasible to be made by the surgical team during surgery. The short conduit assembly time probably does not interfere significantly in the total length of surgery, but when in advance is certain that intestinal resection is be performed, the preparation can be carried out before the operation.

Although the main objective of this article was to describe the device, it is believed that, later, would be interesting to realize a controlled study with representative sample of patients in order to assess its effectiveness in preventing implantation of endometriotic and neoplastic cells in the surgical wound and infection control.

\section{CONCLUSION}

The preparation of the device presented here proved to be feasible and requires no special training and can be performed by the surgical team at reduced costs.

\section{REFERENCES}

1. Barbaros U, Iyibozkurt AC, Gulluoglu M, Barbaros $M$, Erbil $Y$, Tunali $\checkmark$, Mercan S. Endometriotic umbilical port site metastasis after laparoscopy. Am J Obstet Gynecol. 2005 Nov;193(5):1761-3.

2. Bassi MA, Podgaec $S$, Dias Júnior JA, Sobrado CW, D'Amico Filho $\mathrm{N}$, Abrão MS. Endometriose intestinal: uma doença benigna? Rev Assoc Med Bras. 2009; 55(5): 611-6.

3. BerendsFJ,KazemierG, BonjerHJ,LangeJF.Subcutaneousmetastases after laparoscopic colectomy. Lancet. 1994 Jul 2;344(8914):58.

4. Bonnor RM, Ludwig KA. Laparoscopic colectomy for colon cancer: comparable to conventional oncologic surgery? Clin Colon Rectal Surg. 2005 Ago;18(3):174-81.

5. Coelho JCU, Pinho RV, Macedo JJM, Andriguetto PC, Campos ACL. Colectomia laparoscópica: revisão retrospectiva de 120 casos. Rev Col Bras Cir. 2009 Mar/Apr; 36(2):144-7.

6. Fleshman J, Sargent DJ, Green E, Anvari M, Stryker SJ, Beart RW Jr, Hellinger M, Flanagan R Jr, Peters W, Nelson $\mathrm{H}$; for The Clinical Outcomes of Surgical Therapy Study Group. Laparoscopic colectomy for cancer is not inferior to open surgery based on 5 -year data from the COST Study Group trial. Ann Surg. 2007 Out; 246(4):655-62
7. GunesM,KayikciogluF,OzturkogluE,HaberalA.Incisionalendometriosis after cesarean section, episiotomy and other gynecologic procedures. J Obstet Gynaecol Res. 2005 Out;31(5):471-5

8. Horiuchi T, Tanishima H, Tamagawa K, Matsuura I, Nakai H, Shouno Y, Tsubakihara H, Inoue M, Tabuse K. Randomized, controlled investigation of the anti-infective properties of the Alexis retractor/ protector of incision sites. J Trauma. 2007 Jan;62(1):212-5.

9. Horiuchi T, Tanishima H, Tamagawa K, Sakaguchi $S$, Shono $Y$, Tsubakihara H, Tabuse K, Kinoshita Y. A wound protector shields incision sites from bacterial invasion. Surg Infect (Larchmt). 2010 Dez;11(6):501-3.

10. Kesterson JP, Justice T, Terrassa M, Cook C. Abdominal wall endometrioma following cesarean delivery: a case report. J Reprod Med. 2008 Nov;53(11):881-2.

11. Kiran RP, El-Gazzaz GH, Vogel JD, Remzi FH. Laparoscopic approach significantly reduces surgical site infections after colorectal surgery: data from national surgical quality improvement program. J Am Coll Surg. 2010 Ago; 211(2):232-8.

12. LeeSW, Gleason NR, Bessler M, Whelan RL. Port site tumorrecurrence rates in a murine model of laparoscopic splenectomy decreased with increased experience. Surg Endosc. 2000 Set;14(9):805-11.

13. Lee SW. Laparoscopic procedures for colon and rectal cancer surgery. Clin Colon Rectal Surg. 2009 Nov; 22(4):218-24.

14. Pathan ZA, Dinesh U, Rao R. Scar endometriosis. J Cytol. 2010 Jul;27(3):106-8.

15. Reid K, Pockney P, Draganic B, Smith SR. Barrier wound protection decreases surgical site infection in open elective colorectal surgery: a randomized clinical trial. Dis Colon Rectum. 2010 Out;53(10):1374-80.

16. Sookhai S, Redmond HP, Deasy JM. Impervious wound-edge protector to reduce postoperative wound infection: a randomised, controlled trial. Lancet. 1999 Mai 8;353(9164):1585. 